\title{
Multimodal Discourse Analysis of 2012 Governorship Election Campaign Billboards in Ondo State, Nigeria
}

\author{
Prof. Demola Jolayemi \\ Department of English, University of Africa, Toru-Orua.Bayelsa State, Nigeria \\ Dr. Joseph Babasola Osoba \\ Department of English and Literary Studies,Federal University, \\ Ndufu-Alike, Ikwo,Abakaliki, Ebonyi State, Nigeria \\ Dr. Kayode Ariyo* \\ Rufus Giwa Polytechnic,Owo., Ondo State, Nigeria
}

\begin{abstract}
Billboards are widely used in the world for political purposes. The Ondo State 2012 governorship candidates employed billboards for their campaigns. It is observed that an average viewer of the campaign billboards finds it difficult to attain the exact interpretation of the semiotic devices in the pictures as intended by the producers. The objectives of this paper are: the analyses of the political discourse of the multimodal texts in the billboards and the exploration of the nature of the multimodal texts. This paper adopted the text dimension, the discursive practice dimension and the social practice dimensions of Fairclough's $(1992,1995)$ three-dimensional framework. This theoretical framework was used to analyse and discuss the selected campaign billboards. The data collected for this study consisted of three governorship campaign billboards which were purposively selected. The study discovers that colours are meaning signifiers in the selected billboards and that the pictures, colours and verbal anchorages together with the various interpretations given them show the polysemic nature of signs. This paper concludes that visual resources are essential tools employed by campaign billboards' producers. Finally, the study recommends that producers of campaign billboards should ensure simplicity and relevance of the semiotic resources used in the visuals.
\end{abstract}

Keywords: Governorship elections, Campaign billboards, Multimodality, Verbal anchorages, Colours

DOI: $10.7176 / \mathrm{NMMC} / 95-04$

Publication date: January $31^{\text {st }} 2021$

\section{Introduction}

This paper sets out to examine a particular genre that employs a rich set of semiotic modalities (Fairclough, 1995). It analyses the political discourse of the multimodal texts that the three major political parties involved in the 2012 governorship elections in Ondo State, Nigeria massively produced and distributed through the medium of billboards. In Nigeria, billboards are veritable tools for political campaigns (Ezegwu, Ezeji \& Agbasimelo, 2015: 2) and are ideal examples "of impersonal but noticeable communications" - Costas \& Shang (2015: 394). However, it is observed that an average viewer of the campaign billboards finds it difficult to attain the exact interpretation of the semiotic devices in the pictures as intended by the producers in relation to the election campaign. Another major difficulty is the inability to rightly understand the hidden meanings of pictures. Therefore, this paper intends to explore the nature of the multimodal texts (Baldry \& Thibault, 2006) and also show how the political parties used this genre to accomplish goals such as expressing particular ideologies and constructing/conveying social identities and relationships. It equally wishes to examine how social relations were constructed between political parties and the readers/viewers of governorship campaign billboards and also how the parties used billboards to influence voters to cast their votes for them.

The objectives of this study are to:

i) examine the visual components of the billboards;

ii) analyse the use of colours as semiotic resources employed in the billboards and

iii) describe the functional relationship between the verbal and the non-verbal components of the billboards.

However, it is important to consider that these texts were placed in a specific sociocultural context with a particular sociopolitical history that greatly influenced the meaning making potentials of these texts. The following section provides an account of the Ondo State sociopolitical context.

\section{The Ondo State Sociopolitical Context}

This section addresses the 2012 Ondo State governorship election, the main political parties involved, and the candidates' backgrounds. 


\subsection{The 2012 Ondo State Governorship Election}

Ondo State, Nigeria, is one of the thirty six states of Nigeria. Governorship elections in the state, just like others, take place every four years. Many political parties contested the Ondo State Governorship position on October, 20, 2012. However, the three main parties were: the incumbent party, Labour Party (LP), whose candidate, Dr Olusegun Mimiko, won the election; Peoples' Democractic Party (PDP) whose candidate was Chief Barr. Olusola Oke and the Action Congress of Nigeria (ACN) whose candidate was Oluwarotimi Odunayo Akeredolu (SAN). There were other minor political parties like the Accord Party (AP), All Nigeria Peoples' Party (ANPP), Congress of Progressive Change (CPC), etc. The Independent National Electoral Commission (INEC) approved Saturday, 20th October, 2012, as the date for the Ondo State governorship election. (See INEC, 2012, 11 and 3). The official campaigning period lasted from 12th July, 2012 to 19th October, 2012.

\subsection{The Three Main Political Parties in Ondo State in 2012}

In the Nigerian context, it is pretty hard to characterise a political party as solely belonging to the right or to the left. It is obvious that there are more similarities than differences between the right-wing, the centre and the leftwing parties in Nigeria, if their declarations of principles are considered.

The Labour Party is a social democratic political party in Nigeria. The party won 1 out of 360 seats in the House of Representatives and no seats in the Senate during the 21 April, 2007, Nigerian National Assembly election. The party's flagbearer in Ondo State, Olusegun Mimiko, emerged the state governor after winning a judicial challenge.

The Peoples' Democratic Party is a political party in Nigeria. Its policies generally lie towards the right wing of the political spectrum. It has won every Presidential elections since 1999, and is the dominant party in the Fourth Republic. The party has a neoliberal stance in its economic policies and maintains a conservative stance on certain social issues, such as same sex relations.

The Action Congress of Nigeria (ACN), formerly known as Action Congress (AC) is a classical liberal Nigerian political party formed in September, 2006. The party has strong presence in the South West, Mid-West regions and some presence in North Central region. The party later transformed into the current All Progressives Congress (APC).

\subsection{The Candidates}

Olusegun Mimiko, the incumbent governor of Ondo State, was born on 3 October, 1954. He had served as the State Commissioner for Health, Secretary to the State Government and a Federal Minister. He competed in gubernatorial elections on April 14, 2007, and emerged the state governor after winning a judicial challenge on February 23, 2009. He is currently the first and only governor from the Labour Party in Nigeria. Ali Olanusi, the incumbent Deputy Governor, served as his running mate.

Chief Barr. Olusola Oke, a lawyer by profession, was born on 7th April, 1956. He was elected into the House of Representatives in 1992. He served as the Chairman, Ondo State Oil Producing Area Development Commission (OSOPADEC) and National Legal Adviser to PDP. See Coastalnews.com $(2013$, q 1). Saka Lawal, a former Special Adviser to Governor Mimiko, served as his running mate.

Oluwarotimi Odunayo Akeredolu, a Senior Advocate of Nigeria (SAN), was born on 21 July, 1956. He was formerly the president of the Nigerian Bar Association. He served as the State Attorney General and Chairman, Legal Aid Council. Dr. Paul Akintelure, a medical doctor, served as his running mate.

\section{Some Literature Review \\ 3.1. Multimodality}

Kress and van Leeuwen $(2005$, p. 187) are of the opinion that "all texts are multimodal. Language always has to be realised through and come in the company of other semiotic modes." Stivers and Sidnell (2005, p. 1) posit that human social interaction is a product of the intertwined co-operation of different modalities. Kress et al (2001, p. 1) emphasise that "meaning is made in all modes separately, and at the same time, that meaning is an effect of all modes acting jointly." Bo (2018: 132) posits that "Multimodal discourse analysis refers to the analysis of various and different semiotic modes in a discourse."

\subsection{Political Discourse, Power and Politics}

Chilton (2004, p.p. $\mathrm{x}$-xi) suggests that in a bid to explicate this connection, rhetoric, critical theory, and cognitive linguistics among others should be explored. Scholars from semiotic and linguistic fields have contributed to the understanding of the resources that political actors draw upon to structure specific discourses in order to influence, distort, confuse, persuade, convince or motivate citizens. See Teresa (2009, p 23).

Power relations is essentially that of control (van Dijk, 1997, p. 17), where one group or person exercises certain forms of control over others, using various resources available in order to exercise control. One of them is coercive while the other is mental with discourse in its many modes playing an important role in process of 
influencing or controlling people's ideas. (See van Dijk, 1997; 2006).

\subsection{Pragmatics}

Pragmatic theory explains how interlocutors understand sentence meanings (locutionary acts) and speaker meanings (illocutionary act) (see Grice, 1957). The distinctions in meaning as mentioned above and how interlocutors distinguish between potential meanings require a knowledge of speech act theory which was developed by Austin (1962) and further developed by Searle $(1969$, p. 16) who claims that "speaking a language is performing speech acts, acts such as making statements, giving commands, asking questions, making promises, and so on." Levinson (1983, p. 240) summarises the five main types of speech acts as: representatives, directives, commissives, expressives and declaratives.

\subsection{Verbal Anchorages}

According to Bathes (1977, pp. 38-39), anchorage essentially deals with the meaning of images to especially be related to or even depend on the verbal text. It functions at the denotative level by identifying the elements of the scene and the scene itself. However, it functions at the connotative and symbolic level as ideology operates quite significantly here. He submits that an anchorage accounts for visual-verbal dependency and also selects for the reader/viewer one of the many possible interpretations. Noth (1990, p. 453) further suggests that "the juxtaposition of picture and word usually results in a new holistic interpretation of the scripto-pictorial or audio-visual message."

\subsection{Geosemiotics}

Scollon \& Scollon (2003, p.7) state that Geosemiotics involves the interaction order, visual semiotics, and place semiotics.

\subsubsection{The Interaction Order}

Goffman (1983, p. 5) sees the interaction order as a "domain of activity" without direct implications to norms and rules "that is in fact orderly, and that this orderliness is predicated on a large base of shared cognitive presuppositions." He insists that psychobiological elements are of utmost importance in the interaction order.

\subsubsection{Visual Semiotics}

Visual semiotics is a reflection of the representations of Goffman's (1983) interaction order in images and signs. Scollon \& Scollon (2003, p. 86) uphold the semiotic systems developed by Kress and van Leeuwen (1996) which involves participants (represented and interactive), modality, and composition.

\subsubsection{Participants}

There are two types of participants: represented participants and interactive participants. A represented participant refers to any construction element used in a multimodal text, such a visual image, a chart, logo, etc. Interactive participants refer to the persons "who communicate with each other through images, the producers and viewers of images." See Kress and van Leeuwen (2006, p. 114).

The gaze of a person represented in an image may construct two kinds of relationship with the audience. It may make a demand if an image enters into direct eye-contact with the viewer, an offer, if the image directs its gaze elsewhere. The kind of shot employed in an image constructs different relationships with the viewer. While a close shot suggests an intimate relationship, a medium range shot suggests social familiarity, long shots suggest that the viewer and subject may not be acquainted. See Kress and van Leeuwen (2006, pp. 116-129).

\subsection{Modality}

Kress and van Leeuwen (1996, p.161) assert while considering the subject of modality that "visuals can represent people, places and things as though they are real, as though they actually exist in this way or as though they do not - as though they are imaginings, fantasies, etc." Teresa (2009, p.32) agrees with the position of Kress and van Leeuwen (2006, p.154) that an image is regarded as the closest to naturalistic representation that is known to have the highest modality. Alyousef (2016: 1262) concludes that "Different location in an image indicates different vale of information."

\subsection{Composition}

Kress and van Leeuwen (2005) posit that composition in multimodal texts add to the potential meanings that viewers/readers may ascribe to a text. They state that composition involves three signifying systems of information value (Kress \& van Leeuwen, 2006, p. 177), salience (Kress \& van Leeuwen 2005; Rose (2005) and framing, (Kress and van Leeuwen (2006), p. 177). Kress and van Leeuwen (1990, p. 95-98) identify six essential structuring principles in layout. They are: salience, balance, vectors, reading paths, framing and perspective.

\subsection{Place semiotics}

Scollon and Scollon (2003, p. 22) opine that place semiotics centres on "the ways in which the placement of discourse in the material world produces meanings that derive directly from that placement." They present three 
elements of place semiotics as: code preference, inscription, and emplacement.

\subsection{Ethnography}

This study is not entirely 'ethnographic,' yet a thick description from both an emic and an etic perspective in order to adequately contextualize the multimodal texts under investigation is utilised. In order to provide such thick description, alternative field methods such as life histories, photography, written documents, data documenting historical trends, and surveys were utilised in this study. See Harklau (2005, pp. 188-89).

\section{Methodology}

The data collected for this study consists of photographs of governorship campaign billboards collected in the month of October, 2012. The photographs were taken in Akure, Oba-Akoko and Ondo. It should be noted that it is simply not possible to include analysis of every governorship campaign billboard that was initially collected in a work of this size and scope. Only three billboards containing the candidates of LP, PDP and ACN and their running mates were purposively selected.

\section{Analytical Framework}

The analytical framework that was used to analyze this particular genre drew mainly on Fairclough's $(1992,1995)$ model of a three-dimensional analysis. This work drew insights from multimodality/multisemiosis by Kress \& van Leeuwen (1996, 2005, 2006), Scollon and Scollon (2003) and Wodak (2005), geosemiotics by Scollon and Scollon (2003), visual semiotics (Kress and van Leeuwen, 2006), the interaction order (Goffman, 1983), verbal anchorages by Barthes (1977) and ethnographic analysis (Geertz,1973; Norton, 2,000).

\section{Analysis}

While a multimodal text is seen as an integrated text with each part mutually influencing and shaping the meaning of the whole text, however, in order to adequately explore the integrated text, different elements within the text may need to be analysed as individual units. The primary focus of this analysis is on the interplay among photographic images, verbal anchorages and composition.

\section{1. Governorship Campaign Billboard of LP}

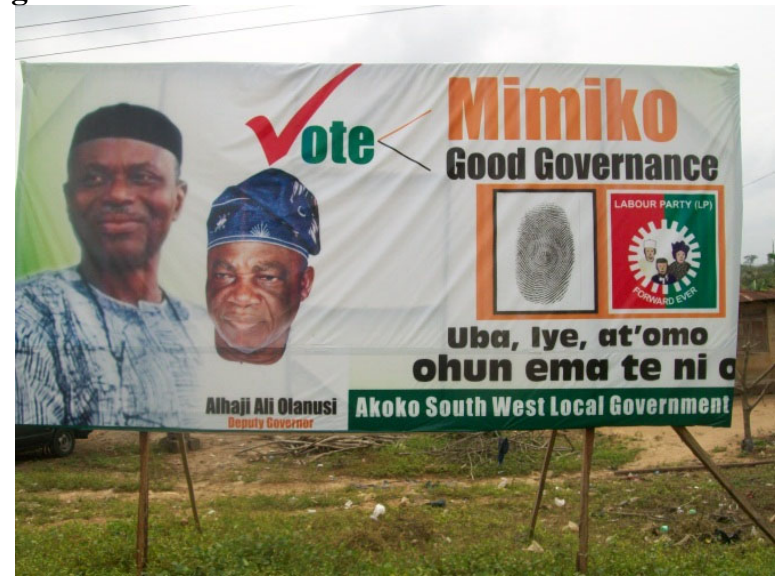

\section{1. 1. Photographic Image}

The picture of Mimiko and his running mate, Olanusi, is a 'close shot', probably trying to create a friendly and personal relationship with the viewer. They are, however, looking at some point down in the distance, not engaging with the viewer. At this point, the viewer of the image is left to imagine what they are "thinking about or looking at, and this can create a powerful sense of empathy or identification with the represented participants" (Kress \& van Leeuwen, ibid., p. 68). It is an "offer", picture where the image 'offers' the represented participants to the viewer as items of information, objects of contemplation, impersonally, as though they were specimens in a display case" (ibid., p. 119). This offer may be interpreted as "look at me... get to know me; I will enter into a relationship with you in the future'. It can be noticed that the represented participants wear buba, Yoruba dresses and caps, 'giving off' the impression of informality that corresponds to "We identify with you. We wear what you wear. We speak your language." Their friendly smiling expression functions as a kind of "visual invitation" (ibid., p. 123) to interact with them. This picture has high modality, since the colours used present them as they are (Kress \& van Leeuwen, ibid. pp. 154-174).

This billboard serves multiple purposes: to help construct Mimiko and Olanusi's identity as one indivisible entity; to introduce them as capable persons to be trusted with a second term; and to convey the idea that they and their party believe in the grassroots and individuals. In compositional terms, this multimodal text achieves rhythm 
and balance which according to Kress and van Leeuwen (ibid.) "form the most bodily aspects of texts, the interface between our physical and semiotic selves...they .... [rhythm and balance] form an indispensable matrix for the production and reception of messages and are vital to human interaction" (p. 203).

\section{1. 2. Verbal Anchorage}

The verbal anchorage is: "Vote Mimiko Good Governance Uba, Iye a'tomo ohun ema te ni o," meaning, "Father, mother and children, this is the place to thumbprint." The verbal anchorage on the billboard encourages voters to vote to re-elect Mimiko for good governance while identifying with them as the voter education is conducted in the Akoko dialectical variation of Yoruba that the people of the area speak.

\section{1. 2. Colour Composition}

The colours on this multimodal text form a combination of high modality (photographic image) with low modality (the rest of the billboard). The colours of the LP logo are present: white, green, red and pink. This composition utilises colours as a resource to make an affective appeal to the viewers/readers. Notice that the letter $v$ of vote is specially designed as a mark of correctness. It seems to suggest that voting him is the only correct thing to do. It is also in red ink, just as teachers mark scripts with red ink. Mimiko is written in pink, the colour of LP, to underscore that he is the flag bearer of the party.

\section{2. Governorship Campaign Billboard of PDP}

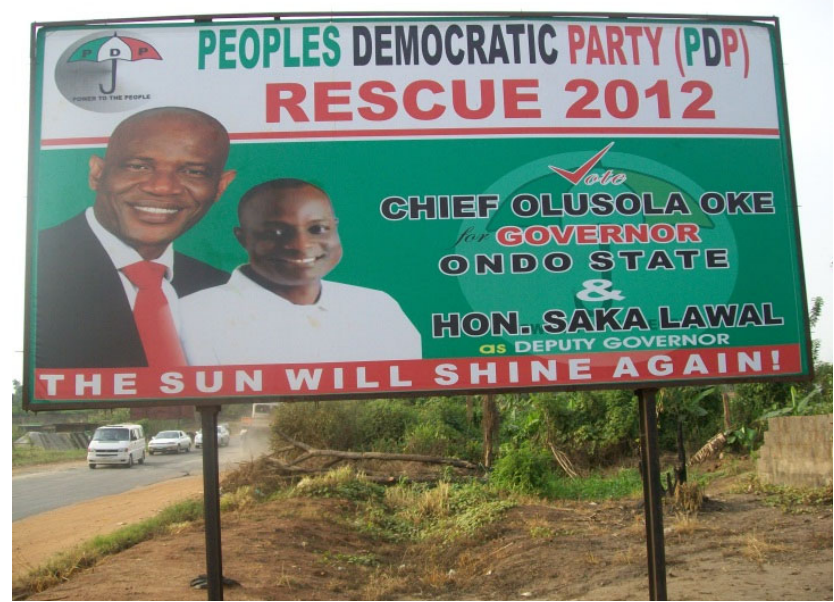

\section{2. 1. Photographic Image}

The picture is a 'close shot', probably trying to create a friendly and personal relationship with the viewer. The attention of the viewers would be drawn to the image of the candidate, Oke, and his running mate, Lawal, on the left hand side. The represented participants' image is clearly the most salient feature of the text due to its size, sharpness of focus, high color saturation, and the sharp contrast between the high modality of their photo and the low modality of their background (Kress \& van Leeuwen 2006, p. 201). They are portrayed at a "friendly and personal distance," creating an "imaginary" relationship between the viewer and them, allowing the viewer to "imaginarily come as close to public figures as if they were...friends" (ibid., p. 125-126). They are in a frontal shot, further reinforcing the imaginary relation between the viewer and the represented participants (ibid, p. 118), while the friendly smiling expression functions as a kind of "visual invitation" (ibid., p. 123) to interact with them. Kress and van Leeuwen (2006) call this kind of frontal shot a demand photo, where the person represented in the image, demands "the 'goods-and-services' that realize a particular social relation" (p. 123), in this case, voting for them. It can be noticed that the candidate wears a black suit and a red tie, suggesting he is set for work while his running mate much younger wears a T-shirt, suggesting he is not under any pressure. They seem to suggest "We will work and play with you."

The image represents them as strong leaders as they realistically and confidently smile and engage the viewer with full eye contact (Kress \& van Leeuwen 2006, p. 140). The image of Oke is bigger because he is to be governor while Lawal is to be deputy. This picture has high modality, since the colours used present them as they are (Kress \& van Leeuwen, ibid. pp. 154-174).

This billboard serves multiple purposes: to help construct Oke and Lawal's identity as one indivisible entity; to introduce them as capable persons to be trusted with a chance at governance; and to convey the idea that they and their party have national spread and acceptability. In compositional terms, this multimodal text achieves rhythm and balance which according to Kress and van Leeuwen (ibid.) "form the most bodily aspects of texts, the interface between our physical and semiotic selves...they... [rhythm and balance] form an indispensable matrix for the production and reception of messages and are vital to human interaction" (p. 203). 


\subsubsection{Verbal Anchorage}

The verbal anchorage is: RESCUE 2012. Vote Chief Olusola Oke Governor Ondo State \& Hon. Saka Lawal as Deputy Governor. THE SUN WILL SHINE AGAIN." The message from the verbal anchorage is that the candidate and his running mate are on a rescue mission. The anchorage tends to suggest that the two of them will be fully involved in running the administration of the state, if elected. That the "sun will shine again" further reinforces their rescue mission strategy and that their administration will bring sunshine to the citizens/residents of the state again.

\subsubsection{Colour Composition}

The colours on this multimodal text form a combination of high modality (photographic image) with low modality (the rest of the billboard). The colours of the PDP logo are present: white, green, and red. This composition utilises colours as a resource to make an affective appeal to the viewers/readers. Notice that the letter $v$ of vote is specially designed as a mark of correctness. It seems to suggest that voting him is the only correct thing to do. It is also in red ink, just as teachers mark scripts with red ink. RESCUE 2012 is written in red, suggesting a kind of danger while the THE SUN WILL SHINE AGAIN is written in white against a red background, suggesting that when finally rescued the state will experience sunshine and peace. The use of a green background could suggest the time of plenty to come.

\section{3. Governorship Campaign Billboard of ACN}

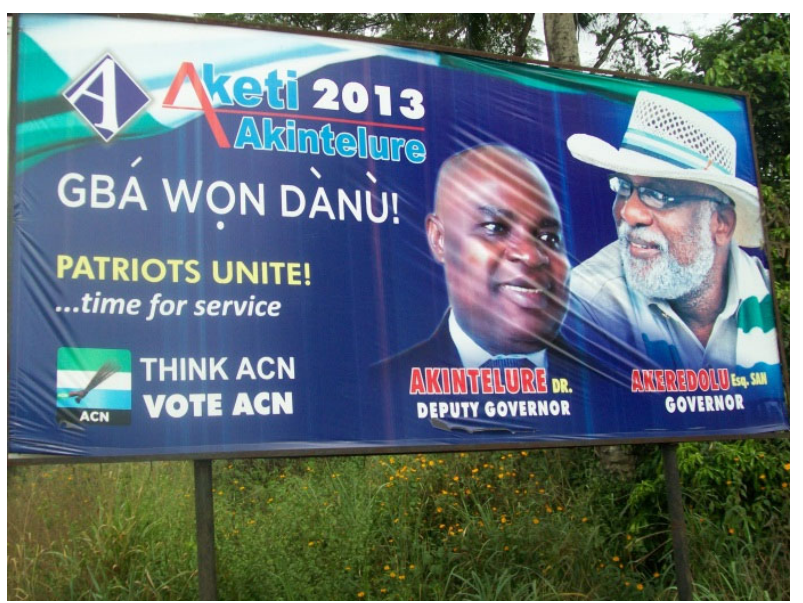

\subsubsection{Photographic Image}

The picture of Akeredolu and his running mate, Akintelure, is a 'close shot', probably trying to create a "friendly and personal distance," relationship with the viewer. They are, however, looking at some point down in the distance, not engaging with the viewer. At this point, the viewer of the image is left to imagine what they are "thinking about or looking at, and this can create a powerful sense of empathy or identification with the represented participants" (Kress \& van Leeuwen, ibid., p. 68). It is an "offer", picture where the image 'offers' the represented participants to the viewer as items of information, objects of contemplation, impersonally, as though they were specimens in a display case" (ibid., p. 119). This offer may be interpreted as 'look at me...get to know me; I will enter into a relationship with you in the future'. It can be noticed that the running mate much younger wears a suit and a tie, suggesting he is set for work while the candidate wears a T-shirt, suggesting he is not under any pressure. They seem to suggest "We will work and play with you." Also, the juxtaposition of the candidate portrayed as an old man with grey hair and his running mate as a young man seems to suggest wisdom of the old and the power of the young that will be seen in their administration, if elected. Their friendly smiling expression functions as a kind of "visual invitation" (ibid., p. 123) to interact with them. This picture has high modality, since the colours used present them as they are (Kress \& van Leeuwen, ibid. pp. 154-174).

This billboard serves multiple purposes: to help construct Akeredolu and Akintelure's identity as one indivisible entity; to introduce them as capable persons to be trusted with a chance at governance; and to convey the idea that they and their party believe in the grassroots and individuals. In compositional terms, this multimodal text achieves rhythm and balance which according to Kress and van Leeuwen (ibid.) "form the most bodily aspects of texts, the interface between our physical and semiotic selves...they... [rhythm and balance] form an indispensable matrix for the production and reception of messages and are vital to human interaction" (p. 203).

\subsubsection{Verbal Anchorage}

The verbal anchorage is: "GBA WON DANU", meaning, SWEEP THEM AWAY. "PATRIOTS UNITE...time for service THINK ACN VOTE ACN." The verbal anchorage directs voters to sweep away the incumbent governor and his men from office. It then harps on the need for all patriots to unite to serve their state and that 
they should live daily for ACN and vote it into power. "GBA WON DANU, meaning, SWEEP THEM AWAY" is from Yoruba, the language that majority of the people of the state speak. It is a way of identifying with the people.

\subsubsection{Colour Composition}

The colours on this multimodal text form a combination of high modality (photographic image) with low modality (the rest of the billboard). The colours of the ACN logo are present: white, green, and blue. Other colours are: red and yellow. This composition utilises colours as a resource to make an affective appeal to the viewer/readers. Notice that the piece of material round the neck of the candidate and his hat as well as a flag on top of the billboard have the colours of the Nigerian national flag. This suggests patriotism.

\section{Findings}

From the analysis of data as shown above, the following is a general summary of the findings of this study. It is discovered that the Ondo State's sociocultural practices greatly enabled both text production and consumption of the governorship campaign billboards. The study discovers that the pictures foreground many significant messages that are not obviously stated in the visual texts. It finds that the pictures as features of semiotic resources adequately use colours as meaning signifiers and when interpreted together with the verbal anchorages they show the polysemic nature of signs. There exists a functional relationship between the visual component and its verbal anchorage in the governorship campaign billboards. The governorship campaign billboards construct social relations with the viewers by the choice of close shot they employ.

\section{Conclusion}

In conclusion, we may state that Ondo State governorship campaign billboards show certain elements of glocalisation. The billboards exhibit globalized Western tendencies in respect of their multimodal composition; however, Ondo State or Yoruba specific cultural, historical and temporal meaning making resources are manifested on these multisemiotic texts.

\section{Recommendations}

Finally, the study recommends that producers of campaign billboards should ensure the simplicity and relevance of the semiotic resources used in the visuals. Also, viewers should explore the hidden meanings of the visuals in billboards.

\section{References}

Alyousef, H. S. (2016) A multimodal discourse analysis of the textual and logical relations in marketing texts written by international undergraduate students. In Functional Linguistics, pp 1-29

Austin, J. L. (1962). How to do things with words. Cambridge, Mass.: Harvard University Press.

Baldry, A. \&Thibault,P. J.(2006).Multimodal transcription and text analysis.London: Equinox.

Barthes, R. (1977). Image, music, text. New York: The Noonday Press.

$\mathrm{Bo}, \mathrm{Xu}$ (2018). Multimodal discourse analysis of the Movie Argo. In English Language Teaching. Vol. 11, No. 4, pp 132-137

Chilton, P. (2004). Analysing political discourse. Theory and practice.London: Routledge.

Coastalnews (2013). Profile of Chief Barr. Olusola Oke Retrieved February 9, 2013 http://www.coastalnews.com/profile/personality-profile/1468-profile-of-chief-barr-olusola-oke.html

Costas, P. \& Shang, E. H. (2015) Billboards and turnout: A randomized field experiment. In Journal of Political Marketing, 14:4, pp 391-404

Ezegwu, D. T., Ezeji, A. \& Agbasimelo, C. I. (2015). A comparative study of the influence of Goodluck Jonathan and Muhammadu Buhari's billboard campaigns on voter's behaviour in Anambra State. In African and Global Perspectives, Vol. 1 No. 2, Pp $1-23$

Fairclough, N. L. (1992). Discourse and social change. Cambridge: Polity Press. Fairclough, N.(1995).Critical discourse analysis: The critical study of language.London: Longman.

Geertz, C. (1973).The interpretation of cultures. New York: Basic Books.

Goffman, E. (1983).The interaction order: American sociological association,1982 Presidential address. American Sociological Review, 48,(1),1-17.

Grice, H. P. (1957). Meaning. Philosophical Review, 66, pp. 377-88.

Harklau, L. (2005). Ethnography and ethnographic research on second language Teaching and learning. In E. Hinkel (Ed.), Handbook of research in second language learning and teaching. Mahwah, NJ :Lawrence Erlbaum

INEC (2013). INEC to conduct Ondo governorship election on 20th October. Retrieved February 9, 2013 $\mathrm{http}: / / \mathrm{www}$.inecnigeria.org/inec-to-conduct-ondo-governorship-election-on-20th-october/

Kress, G., Jewitt, C., Ogborn, J., \& Tstasarelis, C. (2001). Multimodal teaching and learning: the rhetorics of the 
science classroom. London: Continuum International.

Kress, G. \&van Leeuwen, T. (1996). Reading images: The grammar of visual design.London: Routledge.

Kress, G \&van Leeuwen, T. (1999). Representation and interaction: Designing the position of the viewer. In. Coupland, N. \& Jaworski, A. (Eds). The discourse reader (pp. 377- 404). New York: Routledge

Kress, G. \&van Leeuwen, T. (2005). Front pages: (the critical) analysis of newspaper layout.In. Bell, A. \& Garret, P. (Eds.), Approaches to media discourse (pp.186-219). Oxford: Blackwell.

Kress, G. \& van Leeuwen, T. (2006). Reading Images. The grammar of visual design.London: Routledge.

Levinson, S. C. (1983). Pragmatics. Cambridge: Cambridge University.

Noth, W. (1990). Handbook of Semiotics. Bloomington. Idiana University Press.

Norton, B. (2000). Identity and language learning: Gender, ethnicity and educational change. London: Pearson.

Rose, G. (2005). Visual methodologies. London: Sage.

Stivers, T. \& Sidnell, J. (2005). Introduction: Multimodal interaction. In Semiotica. 156-1/4, 1-20

Scollon, R. \& Scollon, S.W. (2003).Discourses in place. Language in the material world.London: Routledge.

Searle, J. R. (1969). Speech acts: An essay in the philosophy of language. Cambridge: Cambridge Univ. Press.

Teresa, A. C. B. (2009). Exploring political institutional and professional discourses in Mexico: A critical multimodal approach. An unpublished PhD Thesis, Department of Linguistics, Macquire University, $\begin{array}{llll}\text { Sydney, } & \text { Australia. } & \text { Retrieved } & \text { February }\end{array}$ from:http://minerva.mq.edu.au:8080/vital/access/services/Download/ mq:6951/SOURCE3?view=truehttp://hdl.handle.net/1959.14/70422

van Dijk, T. A. (1997).Discourse as interaction in society. In van Dijk, T. A. (Ed.), Discourse as social interaction (1-37). London: Sage.

van Dijk, T. A.(2006). Discourse and manipulation. Discourse \& Society, 17(3), pp 359-383.

Wodak, R. (2005). Editorial. Global and local patterns in political discourses. Journal of Language and Politics, $4,(3)$, pp 367-370 